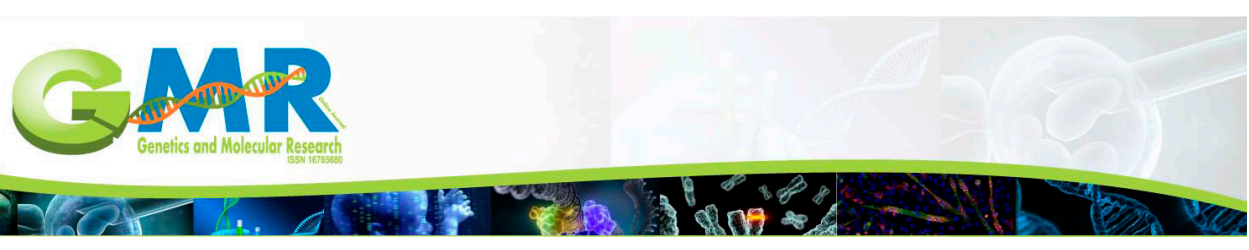

$\underline{\text { Short Communication }}$

\title{
Validation of reference genes for real-time quantitative PCR in tambaqui (Colossoma macropomum)
}

\author{
A.R. Nascimento ${ }^{1}$, G.F. Silva ${ }^{2}$, G.F. Gualberto ${ }^{2}$ and F.L. Almeida ${ }^{2}$ \\ ${ }^{1}$ Faculdade Estácio do Amazonas, Chapada, Manaus, AM, Brasil \\ ${ }^{2}$ Empresa Brasileira de Pesquisa Agropecuária, Amazônia Ocidental, Manaus, \\ AM, Brasil \\ Corresponding author: F.L. Almeida \\ E-mail: fernanda.almeida@embrapa.br \\ Genet. Mol. Res. 15 (4): gmr15049228 \\ Received September 9, 2016 \\ Accepted October 21, 2016 \\ Published December 23, 2016 \\ DOI http://dx.doi.org/10.4238/gmr15049228
}

Copyright (C) 2016 The Authors. This is an open-access article distributed under the terms of the Creative Commons Attribution ShareAlike (CC BY-SA) 4.0 License.

ABSTRACT. Tambaqui, Colossoma macropomum, is the main native
freshwater fish in Brazilian aquaculture. Therefore, intensive research
pressure has been applied to the species to support new technologies
for tambaqui farming. Molecular biology represents a tool that can be
used to investigate every field of applied biology, from fish physiology
to the effects of climate change. Based on the importance of reference
genes for the relative or absolute quantification of gene transcripts, we
cloned and sequenced three candidate reference genes in tambaqui ( $18 \mathrm{~S}$
ribossomal RNA - $18 s$, glyceraldehyde-3-phosphate dehydrogenase -
gapdh, and actin beta - $\beta$-actin), and validated a set of primers for each
gene for use in real-time quantitative PCR. The results were evaluated

Genetics and Molecular Research 15 (4): gmr15049228 
by RefFinder, which indicated that $\beta$-actin is the most suitable reference gene for tambaqui among those studied, followed by $18 \mathrm{~s}$.

Key words: Molecular biology; Aquaculture; Transcription; Tambaqui

\section{INTRODUCTION}

Tambaqui, Colossoma macropomum, a tropical fish from the Orinoco and Amazon basins, is the main native species farmed in Brazil. Traditionally, it is the most consumed fish in the north of Brazil and, consequently, fishing pressure over the years has had a major impact on the wild population of the species. The high demand for this fish, together with reduced natural stock, has boosted tambaqui farming, not only increasing the number of farms but also intensifying production. In 2013, the production of farmed tambaqui was 150,000 tons, which represented $38 \%$ of the total volume of fish cultivated in Brazil in that year (IBGE, 2014). This increase in tambaqui production was possible due to the development of new technologies targeting the species.

Due to the ecological and growing economic importance of tambaqui, studies have been conducted with C. macropomum, including genetic analyses (Santos et al., 2007, 2009), genome sequencing (Animal Genome Project, Embrapa, SEG No. 01.06.01.006.03.00), and more recently, transcriptome analysis, with a study that assessed the changes in tambaqui physiology when exposed to three climate scenarios (Prado-Lima and Val, 2016). In general, these studies aim to preserve the remaining natural stocks and to improve the techniques used for tambaqui farming.

Real-time quantitative PCR (RT-qPCR) is a highly sensitive technique used for the detection of transcripts with a high level of accuracy, in addition to real-time detection of the reaction (Huggett et al., 2005). The use of RT-qPCR is multidisciplinary. It can be applied to quantify (absolutely or relatively) the expression of any target gene, under natural or experimental conditions. However, as this technique is highly sensitive, any RNA degradation that occurs during sampling, handling, or cDNA synthesis might lead to data errors, and can ultimately affect the interpretation of the results. To mitigate this risk and normalize such variations, co-amplification of a reference gene in every sample in which a target gene is amplified is recommended (Bustin et al., 2005). Reference genes usually encode factors involved in cellular processes that are essential to cell survival, and are therefore expressed constitutively. For a gene to be classified as a normalizer, certain criteria must be met; it should not be subject to regulation, its transcription should not be affected by experimental conditions, and it must present minimal variation of expression between tissues and physiological states of the organism (Chervoneva et al., 2010).

As the genome data of tambaqui are not yet available, and considering the immediate and widespread use of molecular tools in fish research, this study aimed to: i) sequence three different candidates [18S ribosomal rRNA $(18 s)$, glyceraldehyde-3-phosphate dehydrogenase (gapdh), and $\beta$-actin ( $\beta$-actin)] for use as reference genes in tambaqui, and ii) to validate RTqPCR assays in eight different organs of tambaqui. These genes were selected on the basis of their use as reference genes in studies with vertebrates, and due to their different roles in the eukaryotic cell cycle. The validation of three reference genes as normalizers for tambaqui RT-qPCR assays represents a great contribution to studies on this species in several areas, such as physiology, health, welfare, reproduction, nutrition, and genetics. Therefore, this study provides an important tool, which can save time and money, for those researchers that aim to quantify any target mRNA in tambaqui.

Genetics and Molecular Research 15 (4): gmr15049228 


\section{MATERIAL AND METHODS}

\section{Fish and RNA extraction}

Six adult tambaqui were captured from the aquaculture facilities of Embrapa Amazônia Ocidental, Manaus, AM, where the fish were produced. Prior to sacrifice, the fish were anesthetized with $10 \%$ benzocaine. Samples of liver, intestine, muscle, heart, gill, brain, and gonads were rapidly collected. The tissue fragments were immediately immersed in RNA Later (Thermo Fisher Scientific ${ }^{\circledR}$, Waltham, MA, USA) and frozen until extraction. Some fragments of the gonads were individually fixed in Bouin solution and embedded in paraffin for histological processing and sexing. An additional eight fish were sampled to obtain six testis and ovary samples. Therefore, a total of 14 fish were used in order to obtain six biological replicates for each organ. All the procedures used during fish handling and sampling followed the ethical principles established by the Brazilian College of Animal Experimentation (COBEA).

Total RNA was isolated by the phenol-guanidine thiocyanate acid method after tissue homogenization. The RNA was quantified (NanoDrop 1000, Thermo Fisher Scientific ${ }^{\circledR}$ ) and its integrity checked using $1 \%$ agarose gel electrophoresis. Contamination of genomic DNA was minimized by DNase treatment (Kit RQ1 RNase-free; Promega ${ }^{\circledR}$, Madison, WI, USA). Random-primed cDNA was synthesized from $2 \mu \mathrm{g}$ total RNA using the High Capacity cDNA Reverse Transcription Kit (Applied Biosystems ${ }^{\circledR}$, Foster, CA, USA).

\section{Gene cloning and sequencing}

Sequences of the tambaqui 18 s, $\beta$-actin, and gapdh genes were obtained by cloning with degenerate primers based on the sequences of these genes from other teleost species. Total DNA and cDNA were used as templates for amplification. The DNA was extracted from tambaqui fin samples as described by de Queiroz et al. (2016), and the cDNA was transcribed from total RNA isolated from the ovary. Cloning was performed in a pGEM-T Easy vector, and sequencing was performed in a 3500 Genetic Analyzer (Applied Byosystems ${ }^{\circledR}$ ). The sequences were deposited in GenBank ( $\beta$-actin GenBank Accession No. KX444555, gapdh GenBank Accession No. KX444556, and 18 s GenBank Accession No. KX444557).

\section{Real-time assay}

Based on these sequences, specific primers were designed for use in RT-qPCR. The amplicon length of each primer set was first visualized on a $1.5 \%$ agarose gel. The efficiency of each primer set was analyzed using a five-point serial dilution $(1: 10)$ of pooled cDNAs from all eight organs, in triplicate. The SYBR Green Fast (Applied Biosystems ${ }^{\mathbb{B}}$ ) fluorescent agent was used in the assay.

RT-qPCR was performed in the 7500 Fast Real-Time PCR System v2.3 (Applied Biosystems $^{\circledR}$ ). The reactions contained $10 \mu \mathrm{L}$ Fast SYBR Green, $100 \mathrm{ng}$ cDNA, $200 \mathrm{nmol}$ primers, and nuclease-free water. The negative control was included in each test and each sample/ control was also run in triplicate. The melting curve was analyzed at the end of the reaction to confirm the presence of only one amplicon in each assay. The expression levels were based on the $\mathrm{Cq}$ (quantification cycle) value. Data are reported as means \pm standard deviation. Statistical differences between each organ for each gene and between genes were analyzed using one-way

Genetics and Molecular Research 15 (4): gmr15049228 
ANOVA followed by the Tukey test. To evaluate the stability of the candidate reference genes using four different algorithms, the tool RefFinder was applied (Xie et al., 2012).

\section{RESULTS}

Fragments of the $18 s$, gapdh, and $\beta$-actin genes, based on the results of cDNA cloning and sequencing, were 202, 491, and 1338 bp in size, respectively, confirming the identity of the genes. Based on sequence analysis, primers for RT-qPCR were designed (Table 1). Primer concentrations of $200 \mathrm{nmol}$ and cDNA concentrations of $100 \mathrm{ng}$ were selected, based on visualization of the amplicons and the remaining primers in agarose gel. The efficiency (E) of each assay was $96.9 \%$ for $18 s, 101.6 \%$ for gapdh, and $99.4 \%$ for $\beta$-actin.

Table 1. Primer sets used for RT-qPCR amplification of 18 s, gapdh, and $\beta$-actin in tambaqui Colossoma macropomum, size of the amplicon, and efficiency of the assays.

\begin{tabular}{l|l|c|c}
\hline Primer & Sequence & Amplicon*(bp) & Efficiency (\%) \\
\hline $18 s$ & F-CAAGAACGAAAGTCGGAGGT & 165 & 96.9 \\
\hline R-actin & F-CGAGCTTTGCAACCATACTCC & & 99.4 \\
\hline Rapdh & R-TCACGTGACACTCGATTCGTGTG & 169 & 101.6 \\
& $\begin{array}{l}\text { F-AGGGACCCAGCCAACTCTC } \\
\text { R-TCAAATGAGCAGAGGCCTTC }\end{array}$ & 99 & \\
\hline
\end{tabular}

*Length of the amplicon derived from the cDNA template.

The expression levels were based on the Cq value. Among the three studied genes, transcript levels of $18 \mathrm{~s}$ were the highest in all tissues (lowest Cq values; Figure 1). There was no statistical difference in the expression of $18 \mathrm{~s}$ and $\beta$-actin among the eight tissues studied (Figure 1). In general, $\beta$-actin and gapdh are expressed at lower levels than $18 s$ in tambaqui (Figure 2).

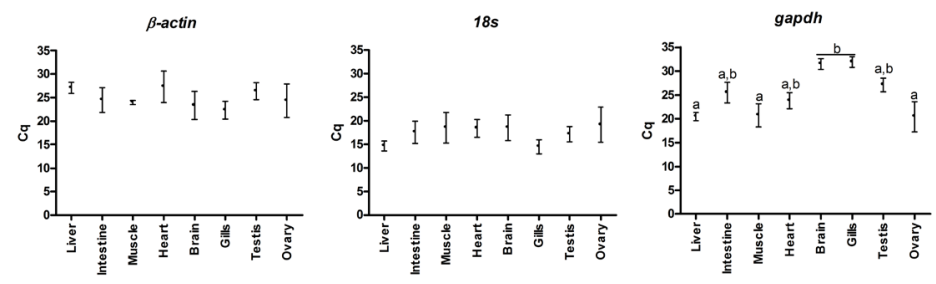

Figure 1. Transcription data for $18 \mathrm{~s}$, gapdh, and $\beta$-actin in liver, intestine, muscle, heart, brain, gills, testis, and ovary of tambaqui Colossoma macropomum (mean \pm standard error of the mean). $\mathrm{Cq}=$ cycle quantification. Different letters indicate significant differences in the transcription of each gene between organs $(\mathrm{P}<0.01)$.

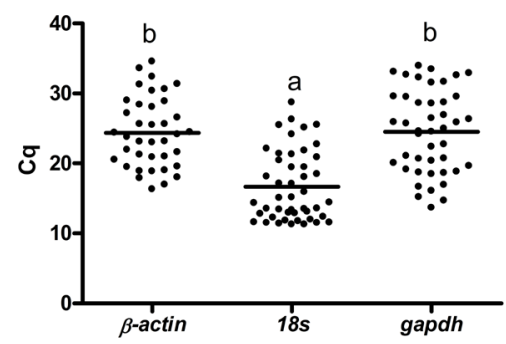

Figure 2. Transcription data of $18 s$, gapdh, and $\beta$-actin in different organs (not specified; $\mathrm{N}=6$ /organ) of tambaqui Colossoma macropomum (mean). Different letters indicate significant differences between the genes $(\mathrm{P}<0.01)$.

Genetics and Molecular Research 15 (4): gmr15049228 
Of the genes evaluated in this study, $\beta$-actin and $18 \mathrm{~s}$ appear to be the most suitable reference genes for tambaqui (Figure 3), according to the RefFinder tool. Data by tissue type are presented in Figure 3.
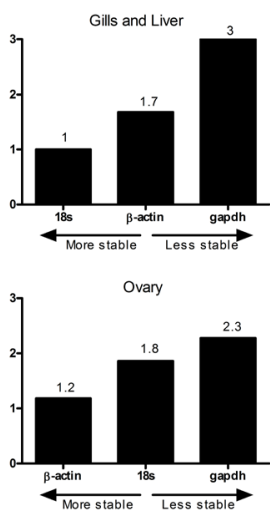

Figure 3. Weight of stability of 18 s, gapdh, and $\beta$-actin in different organs of tambaqui Colossoma macropomum.
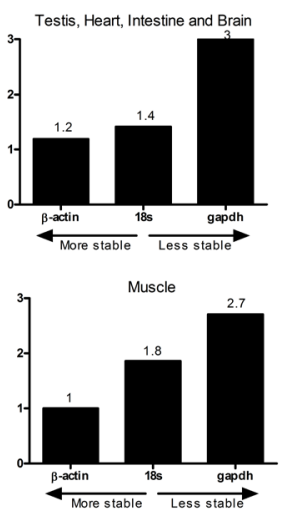

\section{DISCUSSION}

The high sensitivity and degradation of RNA during storage and manipulation represent major problems for the synthesis of cDNA and quantification of transcript levels. Therefore, reference genes are used to normalize the difference between the initial mRNA input and the final number of cDNA copies, as an internal standard of each amplified sample. An ideal reference gene should be constitutively expressed by all cell types and should not be affected by any physiological (age, stage of maturation, body condition, etc.) nor experimental (use of drugs, different temperatures, disease, etc) condition. Among several different reference genes, $18 \mathrm{~s}$, gapdh, and $\beta$-actin are widely used in vertebrates. The $18 \mathrm{~S}$ rRNA gene comprises a subunit of ribosomal RNA (40S) and is thus one of the basic components of all eukaryotic cells. The product of the gapdh gene catalyzes an important energy-yielding step during carbohydrate metabolism, the reversible oxidative phosphorylation of glyceraldehyde3-phosphate in the presence of inorganic phosphate and nicotinamide adenine dinucleotide. In some species, additional functions of GAPDH include nitrosylation of nuclear proteins, regulation of mRNA stability, and as a transferrin receptor on the cell surface of macrophages. Finally, actin is an essential component of the cytoskeleton, and has critical roles in a wide range of cellular processes, including cell migration, cell division, and the regulation of gene expression (Bunnell et al., 2011).

Tambaqui, C. macropomum, is the main native freshwater fish farmed in Brazil. It is estimated that tambaqui farming grows by more than $8 \%$ every year (BRASIL, 2013), and this economic importance has stimulated research efforts to support tambaqui farming. With the aim of providing a basis for real-time quantitative PCR in studies with tambaqui, we cloned and validated a RT-qPCR assay for $18 s$, gapdh, and $\beta$-actin to be used as reference genes in this species.

The efficiency of the assay indicates that all three primer sets are valid for RT-qPCR, since, according to the analysis of relative quantification by Livak and Schmittgen (2001), the E must be between 95 and 105\% for RT-qPCR. Moreover, only one peak was observed on the dissociation melting curves in each sample for all genes, indicating that only one PCR product

Genetics and Molecular Research 15 (4): gmr15049228 
was amplified and confirming the specificity of the assay. Bustin et al. (2009) noted that the presence of dimers may generate false positive tests with SYBR Green, as any (specific and unspecific) amplification generates fluorescence.

To validate the candidate reference genes, RT-qPCR for each gene was performed using cDNA from the liver, intestine, muscle, heart, brain, gills, testis, and ovary of adult tambaqui. The evaluated genes exhibited different levels of transcription in the eight tissues investigated. The $18 \mathrm{~s}$ gene showed the highest transcriptional activity among the three genes, similar to the observations of Wang et al. (2015) in a study in tilapia Oreochromis niloticus. The gapdh and $\beta$-actin genes present similar levels of transcription.

In tambaqui, besides being highly expressed, the $18 \mathrm{~s}$ gene is similarly expressed in all studied organs. The level of $\beta$-actin transcription is also constant in different organs. Conversely, the gapdh gene is highly expressed in the liver, muscle, and ovary of tambaqui, while very low levels of this transcript were observed in the brain and gills.

Among all the evaluated organs, the tambaqui ovary seems to exhibit the most variable expression of $18 s$, gapdh, and $\beta$-actin. This probably reflects the high metabolism and dynamics of the tissue, as marked changes in cellular components constitute folliculogenesis, which affect the basal metabolism of these organs. There is massive variation in gene transcription within the gonads between the immature and mature stage, which also explains the variation in constitutive gene expression. In tilapia, transcription of the reference genes increases significantly during oogenesis, especially during periods of high vitellogenic protein production (Deloffre et al., 2012).

Finally, the stability of the genes was evaluated using RefFinder, which is a webbased tool that evaluates and screens candidate reference genes based on the ranking of four different algorithms, geNorm, Normfinder, BestKeeper, and DeltaCt (Xie et al., 2012). These algorithms assess inter- and intra-group variations to estimate individual stability values for each gene (Vandesompele et al., 2002; Andersen et al., 2004; Pfaffl et al., 2004; Silver et al., 2006). Therefore, RefFinder combines the results of the best programs available and selects the most suitable reference gene from a set of candidates.

$\beta$-actin was the most stable gene in the testis, heart, intestine, brain, muscle, and ovary of tambaqui. Our results indicate that $18 \mathrm{~s}$ is the most suitable gene in the liver and gills for the normalization of RT-qPCR. However, the combined use of three or more genes as an internal control is recommended for the proper normalization of RT-qPCR assays (Bustin et al., 2005).

Taken together, these data indicate that the primers developed in the present study are reliable for RT-qPCR, and therefore, confirm the use of $\beta$-actin, 18 s, and gapdh as good reference genes for tambaqui. Moreover, our results indicate that $\beta$-actin is the most stable gene within the eight organs evaluated, followed by $18 s$ and gapdh. These data will contribute to studies on the biology of tambaqui, from basic to applied research.

\section{Conflicts of interest}

The authors declare no conflict of interest.

\section{ACKNOWLEDGMENTS}

Research supported by Fundação de Amparo à Pesquisa do Estado do Amazonas (FAPEAM) for the project (\#3139/2012) and for providing the fellowship to Gilvana Gualberto,

Genetics and Molecular Research 15 (4): gmr15049228 
and the financial support of Conselho Nacional de Desenvolvimento Científico e Tecnológico (CNPq) for providing the fellowship to Aquila do Nascimento. We appreciate the technical support of Irani da Silva de Morais during sampling and Jefferson Cruz in the laboratory.

\section{REFERENCES}

Andersen CL, Jensen JL and Ørntoft TF (2004). Normalization of real-time quantitative reverse transcription-PCR data: a model-based variance estimation approach to identify genes suited for normalization, applied to bladder and colon cancer data sets. Cancer Res. 64: 5245-5250. http://dx.doi.org/10.1158/0008-5472.CAN-04-0496

BRASIL. (2013) Ministério da Pesca e Aquicultura. Boletim Estatística da Pesca e Aquicultura no Brasil. Ministry of Fisheries and Aquaculture, Brasília. [http://bibspi.planejamento.gov.br/handle/iditem/453]. Accessed June 30, 2016.

Bunnell TM, Burbach BJ, Shimizu Y and Ervasti JM (2011). $\beta$-Actin specifically controls cell growth, migration, and the G-actin pool. Mol. Biol. Cell 22: 4047-4058. http://dx.doi.org/10.1091/mbc.E11-06-0582

Bustin SA, Benes V, Nolan T and Pfaffl MW (2005). Quantitative real-time RT-PCR--a perspective. J. Mol. Endocrinol. 34: 597-601. http://dx.doi.org/10.1677/jme.1.01755

Bustin SA, Benes V, Garson JA, Hellemans J, et al. (2009). The MIQE guidelines: minimum information for publication of quantitative real-time PCR experiments. Clin. Chem. 55: 611-622.http://dx.doi.org/10.1373/clinchem.2008.112797

Chervoneva I, Li Y, Schulz S, Croker S, et al. (2010). Selection of optimal reference genes for normalization in quantitative RT-PCR. BMC Bioinformatics 11: 253.http://dx.doi.org/10.1186/1471-2105-11-253

de Queiroz CA, Sousa NR, da Silva GF and Inoue LA (2016). Impacts of stocking on the genetic diversity of Colossoma macropomum in central Amazon, Brazil. Genet. Mol. Res. 15. http://dx.doi.org/10.4238/gmr.15027700

Deloffre LA, Andrade A, Filipe AI and Canario AV (2012). Reference genes to quantify gene expression during oogenesis in a teleost fish. Gene 506: 69-75. http://dx.doi.org/10.1016/j.gene.2012.06.047

Huggett J, Dheda K, Bustin S and Zumla A (2005). Real-time RT-PCR normalisation; strategies and considerations. Genes Immun. 6: 279-284. http://dx.doi.org/10.1038/sj.gene.6364190

IBGE (2014) Pesquisa da pecuária municipal. In: IBGE. Rio de Janeiro. 42: 1-39. Available at [http://biblioteca.ibge.gov. br/visualizacao/periodicos/84/ppm_2014_v42_br.pdf]. Accessed June 30, 2016.

Livak KJ and Schmittgen TD (2001). Analysis of relative gene expression data using real-time quantitative PCR and the 2(- $\Delta \Delta \mathrm{C}(\mathrm{T}))$ Method. Methods 25: 402-408. http://dx.doi.org/10.1006/meth.2001.1262

Pfaffl MW, Tichopad A, Prgomet C and Neuvians TP (2004). Determination of stable housekeeping genes, differentially regulated target genes and sample integrity: BestKeeper-Excel-based tool using pair-wise correlations. Biotechnol. Lett. 26: 509-515.http://dx.doi.org/10.1023/B:BILE.0000019559.84305.47

Prado-Lima M and Val AL (2016). Transcriptomic characterization of tambaqui (Colossoma macropomum, Cuvier, 1818) exposed to three climate change scenarios. PLoS One 11: e0152366.http://dx.doi.org/10.1371/journal.pone.0152366

Santos M, Rufino M and Farias I (2007). High levels of genetic variability and panmixia of the tambaqui Colossoma macropomum (Cuvier, 1818) in the main channel of the Amazon River. J. Fish Biol. 71: 33-34. http://dx.doi. org/10.1111/j.1095-8649.2007.01514.x

Santos MD, Hrbek T and Farias IP (2009). Microsatellite markers for the tambaqui (Colossoma macropomum, Serrasalmidae, Characiformes), an economically important keystone species of the Amazon River floodplain. Mol. Ecol. Resour. 9: 874-876.http://dx.doi.org/10.1111/j.1755-0998.2008.02331.x

Silver N, Best S, Jiang J and Thein SL (2006). Selection of housekeeping genes for gene expression studies in human reticulocytes using real-time PCR. BMC Mol. Biol. 7: 33. http://dx.doi.org/10.1186/1471-2199-7-33

Vandesompele J, De Preter K, Pattyn F, Poppe B, et al. (2002). Accurate normalization of real-time quantitative RT-PCR data by geometric averaging of multiple internal control genes. Genome Biol. 3: H0034. http://dx.doi.org/10.1186/ gb-2002-3-7-research0034

Wang E, Wang K, Chen D, Wang J, et al. (2015). Evaluation and selection of appropriate reference genes for real-time quantitative PCR analysis of gene expression in nile tilapia (oreochromis niloticus) during vaccination and infection. Int. J. Mol. Sci. 16: 9998-10015.http://dx.doi.org/10.3390/ijms16059998

Xie F, Xiao P, Chen D, Xu L, et al. (2012). miRDeepFinder: a miRNA analysis tool for deep sequencing of plant small RNAs. Plant Mol. Biol. 80: 75-84. http://dx.doi.org/10.1007/s11103-012-9885-2

Genetics and Molecular Research 15 (4): gmr15049228 